\title{
The zinc finger protein TcZFP2 binds target mRNAs enriched during Trypanosoma cruzi metacyclogenesis
}

\author{
Patricia Alves Mörking', Rita de Cássia Pontello Rampazzo', Pegine Walrad², \\ Christian Macagnan Probst', Maurilio José Soares', Daniela Fiori Gradia', \\ Daniela Parada Pavoni', Marco Aurélio Krieger ${ }^{1}$, Keith Matthews', \\ Samuel Goldenberg 1 , Stenio Perdigão Fragoso ${ }^{1 /+}$, Bruno Dallagiovanna ${ }^{1}$
}

${ }^{1}$ Instituto Carlos Chagas-Fiocruz, Curitiba, PR, Brasil ${ }^{2}$ Centre for Immunity, Infection and Evolution, School of Biological Sciences, University of Edinburgh, Edinburgh, UK

\begin{abstract}
Trypanosomes are parasitic protozoa in which gene expression is primarily controlled through the regulation of $m R N A$ stability and translation. This post-transcriptional control is mediated by various families of RNA-binding proteins, including those with zinc finger $\mathrm{CCCH}$ motifs. $\mathrm{CCCH}$ zinc finger proteins have been shown to be essential to differentiation events in trypanosomatid parasites. Here, we functionally characterise TcZFP2 as a predicted post-transcriptional regulator of differentiation in Trypanosoma cruzi. This protein was detected in cell culturederived amastigotes and trypomastigotes, but it was present in smaller amounts in metacyclic trypomastigote forms of T. cruzi. We use an optimised recombinant RNA immunopreciptation followed by microarray analysis assay to identify TcZFP2 target mRNAs. We further demonstrate that TcZFP2 binds an A-rich sequence in which the adenosine residue repeats are essential for high-affinity recognition. An analysis of the expression profiles of the genes encoding the TcZFP2-associated $m R N A$ s throughout the parasite life cycle by microarray hybridisation showed that most of the associated $m R N A s$ were upregulated in the metacyclic trypomastigote forms, also suggesting a role for TcZFP2 in metacyclic trypomastigote differentiation. Knockdown of the orthologous Trypanosoma brucei protein levels showed ZFP2 to be a positive regulator of specific target $m R N A$ abundance.
\end{abstract}

Key words: Trypanosoma cruzi - CCCH zinc finger protein - RNA-binding protein - cell differentiation

In eukaryotes, post-transcriptional regulation involves cis control elements, which are generally present in the untranslated regions (UTRs) of mRNAs and trans-acting factors, such as non-coding RNAs and RNA-binding proteins (RBPs). RBPs are major regulators of mRNA processing, transport, stability and translation and are classified according to their RNA-binding domains (Lunde et al. 2007). Proteins with zinc finger domains may interact either with other proteins or with nucleic acids. Zinc finger domains with $\mathrm{CCCH}$ motifs bind to RNAs with high affinity and are present in proteins that are involved in the post-transcriptional regulation of mRNAs (Auweter et al. 2006). RBPs of this class have been identified in trypanosomatid protozoan parasites, which have been shown to contain approximately 50 proteins with at least one zinc finger domain (Hendricks \& Matthews 2007, Kramer et al. 2010).

Financial support: CNPq, Fundação Araucária, FIOCRUZ, CAPES MJS, MAK, SG, SPF and BD received fellowships from CNPq. PAM and DG received fellowships from CAPES, RCPR received support from FIOCRUZ, PBW and KRM are supported by a programme from the Wellcome Trust.

PAM and RCPR contributed equally to this work.

+ Corresponding author: sfragoso@fiocruz.br

Received 21 November 2011

Accepted 12 April 2012
Several species of trypanosomatids cause various diseases in humans and domestic animals, with major impacts on human health and on the economies of developing countries. The implicated species include Trypanosoma cruzi, Trypanosoma brucei spp and Leishmania spp. T. cruzi is the causal agent of Chagas disease, which affects millions of people in the Americas. This parasite has a complex life cycle, with two hosts and at least four well-defined forms (de Souza 2002). Within the insect vector, the non-infectious replicative forms (epimastigotes) are converted into non-replicating infectious forms (metacyclic trypomastigotes) in a process called metacyclogenesis. This differentiation process can be mimicked in vitro through the use of well-defined chemical media (Contreras et al. 1985, 1988) and this system constitutes an excellent model for studying differential gene expression throughout the life cycle of the parasite.

Gene expression is controlled almost entirely by posttranscriptional regulation in trypanosomes (reviewed by Clayton \& Shapira 2007). This regulation typically involves polycistronic transcription, mRNA maturation by trans-splicing and the editing of mitochondrial transcripts. No canonical RNA pol II promoters have been described and a clear case in which transcription initiation is regulated for this polymerase has yet to be reported. Moreover, genes that are present in the same polycistronic unit and transcribed as a single pre-mRNA display different patterns of expression, suggesting that regulation occurs during the later stages of mRNA metabolism. Post-transcriptional regulation in trypano- 
somes has been reported to primarily involve the control of mRNA stability and translation. The exosome and deadenylation complexes have been identified as the primary regulators of transcript stability via several different degradation pathways (reviewed by Clayton \& Shapira 2007, Haile \& Papadopoulou 2008). In T. cruzi, RBPs of the RRM type are involved in the stage-specific regulation of mucin surface proteins, which bind to the ARElike elements in the 3' UTRs of mRNAs (D'Orso et al. 2003). Translational regulation has also been described in trypanosomes and may involve a number of mechanisms, including the control of elongation or termination (Nardelli et al. 2006) and the differential mobilisation of transcripts to polysomes (Ávila et al. 2003, Walrad et al. 2009). RBPs associate together in macromolecular structures called ribonucleoprotein particles (RNPs), which may also form complex structures, such as various types of RNA granules. The processing bodies and stress granules that are generated in response to stress conditions have been described for T. cruzi (Cassola et al. 2007) with different dynamics at different stages of the parasite life cycle (Holetz et al. 2007).

A subfamily of small RBPs with a single $\mathrm{CCCH}$ zinc finger motif has been described in trypanosomes. In T. brucei, three different proteins from this subfamily (TbZFP1, TbZFP2 and TbZFP3) have been described and are involved in cell differentiation. TbZFP1 displays stage-specific expression, whereas TbZFP2 and TbZFP3 are constitutively expressed (Hendricks et al. 2001, Hendricks \& Matthews 2005, Paterou et al. 2006). Knockout studies and RNAi assays have shown that these proteins are important for the progression of the parasite life cycle (Hendricks et al. 2001, Hendricks \& Matthews 2005, Paterou et al. 2006). Immunoprecipitation assays have shown that TbZFP3 associates with procyclin transcripts, modulating their translation (Walrad et al. 2009). We previously identified protein TcZFP1 in T. cruzi and isolated two orthologues of the T. brucei TbZFP2 and TbZFP3 proteins (Mörking et al. 2004). The biochemical properties of these proteins were subsequently analysed in vitro (Caro et al. 2005). Interestingly, it has been shown that in both T. brucei and T. cruzi, these small ZFP proteins interact both in vivo and in vitro (Caro et al. 2005, Paterou et al. 2006), which suggests that the proteins may regulate similar biological processes in a coordinated manner. Supporting this theory, the TbZFP1-interacting domain of TbZFP3 is essential for protein function and polysomal association (Paterou et al. 2006).

Here, we examine the function of TcZFP2 in T. cruzi and its role as a post-transcriptional regulator that promotes $T$. cruzi differentiation to the human infectious metacyclic trypomastigote forms. We used a variation of RNA immunoprecipitation followed by microarray analysis (RIP-CHIP) that uses the recombinant RBP to identify mRNA targets (rRIP-CHIP) (Townley-Tilson et al. 2006). We further demonstrate that TcZFP2 binds an A-rich sequence for which the adenosine residue repeats are essential for high-affinity recognition. Knockdown of the orthologous T. brucei protein levels shows ZFP2 to be a positive regulator of specific target mRNA abundance.

\section{MATERIALS AND METHODS}

Parasite culture and transfection - T. cruzi culture T. cruzi clone Dm28c (Contreras et al. 1985) was used throughout this study. Epimastigotes of T. cruzi Dm28c were cultured at $28^{\circ} \mathrm{C}$ in liver infusion tryptose (LIT) medium supplemented with $10 \%$ bovine foetal serum. The culture was initiated by adding $5 \times 10^{5} 1 \times 10^{6}$ cells mL $^{-1}$ and the parasites were harvested when the culture reached a cell density of $1-2 \times 10^{7}$ cells $\mathrm{mL}^{-1}$ (log-phase parasites).

To obtain metacyclic trypomastigotes, $T$. cruzi epimastigotes were allowed to differentiate under chemically defined conditions (TAU3AAG medium) as previously described (Bonaldo et al. 1988, Contreras et al. 1988). Briefly, epimastigotes in the late exponential growth phase were harvested from LIT medium by centrifugation and were subjected to nutritional stress for $2 \mathrm{~h}$ in triatomine artificial urine (TAU) $(190 \mathrm{mM} \mathrm{NaCl}, 17 \mathrm{mM}$ $\mathrm{KCl}, 2 \mathrm{mM} \mathrm{MgCl}, 2 \mathrm{mM} \mathrm{CaCl}_{2}$ and $8 \mathrm{mM}$ sodium phosphate buffer, $\mathrm{pH}$ 6.0) at a density of $5 \times 10^{8}$ cells $\mathrm{mL}^{-1}$. The epimastigotes were subsequently used to inoculate cell culture flasks containing TAU3AAG (TAU supplemented with $50 \mathrm{mM}$ sodium glutamate, $10 \mathrm{mM}$ L-proline, $2 \mathrm{mM}$ sodium aspartate and $10 \mathrm{mM}$ glucose) at a density of $5 \times 10^{6}$ cells $\mathrm{mL}^{-1}$ at $28^{\circ} \mathrm{C}$. Metacyclic trypomastigotes were purified by DEAE-51 chromatography from the TAU3AAG culture supernatant after $72 \mathrm{~h}$ of incubation.

To obtain cell-derived trypomastigotes, metacyclic trypomastigote forms were collected as described above and were used to infect Vero cells. The Vero cells were grown in RPMI medium supplemented with 5\% bovine foetal serum (Invitrogen, Carlsbad, CA, USA), $100 \mathrm{UI} /$ $\mathrm{mL}$ penicillin, $10 \mu \mathrm{g} / \mathrm{mL}$ streptomycin and $2 \mathrm{mM}$ glutamine at $37^{\circ} \mathrm{C}$ in an atmosphere of $5 \% \mathrm{CO}_{2}$ until the cells reached $50-70 \%$ confluence. The cell monolayer was subsequently infected with metacyclic trypomastigotes (150 parasites for 1 host cell). After $24 \mathrm{~h}$, the medium was discarded to remove the parasites in the supernatant. The cells were then washed once with RPMI and new medium was added to the culture flask. Cell-derived trypomastigotes were released into the supernatant four days after infection and were harvested by centrifugation at $5,000 \mathrm{~g}$ for $10 \mathrm{~min}$.

Culture amastigotes were obtained by disrupting the Vero cells 10 days after the culture was infected with metacyclic trypomastigotes as described above. The amastigotes were harvested by centrifugation at $1,000 \mathrm{~g}$ for $5 \mathrm{~min}$.

T. brucei culture - Procyclic form T. brucei Lister 427 trypanosomes engineered for TbZFP2-TY ectopic expression and TbZFP2 RNAi have been described previously (Hendricks et al. 2001). These trypanosomes were regenerated by Amaxa nucleofection and were selected and cultured in SDM-79 media as previously described (Paterou et al. 2006).

The cloning and production of the recombinant protein and antibodies - The Tczfp2 gene (GenBank accession ABW69369) was amplified by polymerase chain reaction (PCR) using the primers TcZFP2f (GGGGGGATCCATGTCCTACCCGAATCGTTA) and TcZFP2r 
(GGGGAAGCTTTCACTGGGTCTGTGCGGGCA) and was subsequently inserted into a pQE30 plasmid (Qiagen, Germany) digested with BamHI and HindIII restriction enzymes. The restriction enzyme sites are underlined, whereas the start and stop codons are in bold font. The resulting construct was used to transfect Escherichia coli M15. The recombinant protein was purified under native conditions using Ni-NTA resin (Qiagen, Germany) according to the manufacturer's protocol. A polyclonal antiserum (anti-TcZFP2) was raised in $\mathrm{BALB} / \mathrm{c}$ mice through immunisation with the TcZFP2 recombinant protein.

Gel shift assays - Binding reactions and an electrophoretic mobility shift assay (EMSA) were performed as previously described (Mörking et al. 2004) with $0.5 \mathrm{ng}$ of the appropriate radioactively labelled oligonucleotides $(10,000 \mathrm{cpm})$. The binding reactions were performed by adding $500 \mathrm{ng}$ of the recombinant TcZFP2 protein to the reaction mixture under the same conditions.

Oligoribonucleotides were obtained from Qiagen Operon (Supplementary data). The oligonucleotides were all end-labelled with T4 polynucleotide kinase (Roche, Switzerland) and $\left[\gamma-{ }^{32} \mathrm{P}\right]$ ATP (Amersham Biosciences, England) as previously described (Mörking et al. 2004).

The apparent dissociation constants $\left(\mathrm{K}_{\mathrm{d}}\right)$ of the ribonucleoprotein complexes of the recombinant TcZFP2 protein with different probes were determined by EMSA as previously described (Mörking et al. 2004).

RNA pull-down assay - For the recombinant protein pull-down assays, 200 pmol of recombinant His-tagged TcZFP2 protein were incubated with $90 \mu \mathrm{g}$ of total RNA from epimastigotes in $500 \mu \mathrm{L}$ of EMSA buffer $(1 \mathrm{mM}$ Tris- $\mathrm{HCl} \mathrm{pH} 8.0,1 \mathrm{mM} \mathrm{KCl}, 1 \mathrm{mM} \mathrm{MgCl}$ and $1 \mathrm{mM}$ DTT) at $4^{\circ} \mathrm{C}$ for $1 \mathrm{~h}$ in the presence of heparin and spermidine as competitors. After the incubation, reaction mixtures were incubated with $200 \mu \mathrm{L}$ of Ni-NTA resin (Qiagen, Germany) overnight at $4^{\circ} \mathrm{C}$. Bound and unbound RNA samples were recovered. The bound sample was washed with the same buffer three times. After washing, the RNA present in both of the fractions was purified.

RNA purification - RNA from the pull-down assays was purified with an RNeasy mini kit (Qiagen, Germany). Linearly amplified RNA (aRNA) was generated with the MessageAmp aRNA kit (Ambion, USA) according to the manufacturer's instructions. cDNA was synthesised from $1 \mu \mathrm{g}$ of total or affinity-purified RNAs with random primers (USB, USA) and reverse transcriptase IMPROM II (Promega, USA) as recommended by the manufacturer.

Microarray analysis - The microarray was constructed with 70-mer oligonucleotides. Due to the hybrid and repetitive nature of the sequenced $T$. cruzi strain, all of the coding regions (CDS) identified in the genome (version 3) were retrieved and clustered by the BLASTClust program using the criteria of $40 \%$ coverage and $75 \%$ identity. For probe design, we used ArrayOligoSelector software (v. 3.8.1) with a parameter of $50 \% \mathrm{G}+\mathrm{C}$ content. We obtained 10,359 probes for the longest $T$. cruzi CDS of each cluster, 393 probes corresponded to the genes of an external group (Cryptosporidium hominis) and 64 spots contained only spotting solution (SSC 3X), resulting in a total of 10,816 spots. These oligonucleotides were spotted from a $50 \mu \mathrm{M}$ solution onto poly-L-lysine-coated slides and were cross-linked with $600 \mathrm{~mJ}$ of ultraviolet irradiation. Each probe corresponding to a T. cruzi gene was identified according to the T. cruzi Genome Consortium annotation (genedb.org). We compared bound and unbound RNA, which were extracted from three independent pull-down assays in a dye-swap design that included four slides. Microarray images were analysed by Spot software (hca-vision.com/product_spot.html). The Limma package (Smyth 2004) was used for background correction using the normexp method, intra-slide normalisation by the printtiploess method and inter-slide normalisation by the quantile method. The results for the two intra-slide probe replicates were subsequently averaged. The pull-down results were averaged and probes displaying more than a two-fold difference between the bound and unbound fractions were selected.

Quantitative real time PCR (qRT-PCR) analysis Total RNA from parental and transgenic procyclic cell lines was harvested and purified using Qiagen RNAeasy columns using on-column DNAse digestion. cDNA was generated using an oligo $\left(\mathrm{dT}_{18}\right)$ primer for reverse transcription and subsequent qRT-PCR reactions were performed as previously described (Walrad et al. 2009). The actin cDNA was amplified as previously described (Walrad et al. 2009). The primers used to amplify the T. brucei orthologs of TcZFP2-associated transcripts are shown in Supplementary data.

Ethics - The animal experiments were approved by the Ethical Committee on Animal Experimentation of the Oswaldo Cruz Foundation (protocol P-0434/07).

\section{RESULTS}

TcZFP2 is a cytoplasmic protein displaying reduced expression in the metacyclic stage.

His-tagged TcZFP2 recombinant protein (Fig. 1) was used to raise a polyclonal antiserum in mice. On Western blots of cell extracts from epimastigotes, we detected a band approximately $20 \mathrm{kDa}$ in size that corresponded to the expected molecular mass of TcZFP2. This protein was also detected in cell culture-derived amastigotes and trypomastigotes, but it was present in lesser amounts in metacyclic trypomastigote forms (Fig. 2A). A detailed analysis of the metacyclogenesis process revealed that TcZFP2 was present at similar levels in different parasites and that it was present in lesser amounts only in metacyclic forms (Fig. 2B).

The identification of putative TcZFP2-associated $m R N A s$ - We used an optimised version of the RIP-CHIP to identify the transcripts bound by TcZFP2 (TownleyTilson et al. 2006). The recombinant protein was bound to Ni-NTA-agarose resin and was then incubated with total RNA purified from epimastigote cells. RNA-protein complexes were allowed to form in vitro and RNA was purified from the bound and flow-through fractions and then amplified. The resulting cRNAs were labelled and hybridised to a $T$. cruzi oligonucleotide microarray. We conducted three independent pull-down assays, each of which was followed by microarray hybridisation. As 
a negative control, we conducted a mock assay in which no recombinant protein was added and an independent assay using a recombinant GST protein. No RNA was detectable in the bound fractions of both assays, even after amplification; thus, no microarray hybridisations were performed (not shown). A T. cruzi oligonucleotide microarray was analysed by competitive hybridisation using the non-bound fraction as the reference population in dye-swap assays.

Enrichment was observed for 223 genes among the three independent assays (Supplementary data). It has been suggested that RBPs also regulate the function of the associated mRNAs in trypanosomes (Noé et al. 2008, Kabani et al. 2009, Ouellette \& Papadopoulou 2009). Therefore, we looked for functional relationships between the identified mRNAs. An analysis of the enriched genes

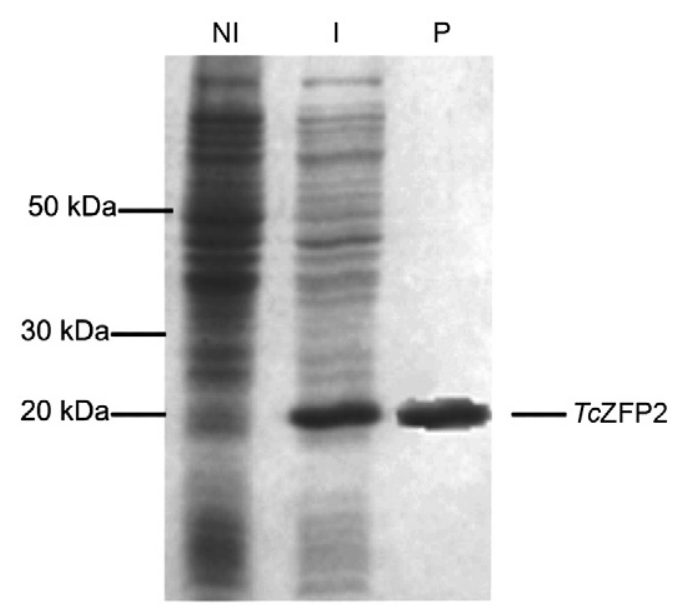

Fig. 1: TcZFP2 was expressed in Escherichia coli and purified by Ni-NTA affinity chromatography. Protein extracts were separated by sodium dodecyl sulfate polyacrylamide gel electrophoresis and stained with Coomassie Blue. Molecular weight markers (kDa) are indicated. I: IPTG-induced cultures; NI: cellular extracts from noninduced; P: purified protein.
A
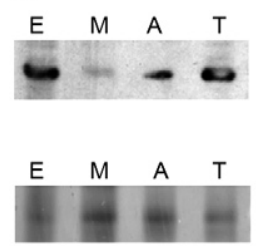
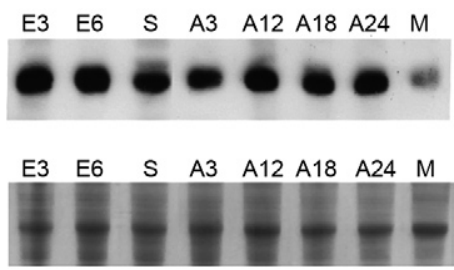

Fig. 2: TcZFP2 production is downregulated in metacyclic trypomastigotes. A: we analyzed the profile of TcZFP2 production in Trypanosoma cruzi epimastigotes (E), metacyclic trypomastigotes (M), amastigotes (A) and trypomastigote forms (T); B: TcZFP2 levels during T. cruzi metacyclogenesis in vitro; E3: exponential phase; E6: stationary phase epimastigotes; M: metacyclic trypomastigotes; S: stressed parasites, parasites adhering to the plate for $3 \mathrm{~h}$ (A3), $12 \mathrm{~h}$ (A12), 18 h (A18) and 24 h (A24). Coomassie Blue-stained sodium dodecyl sulfate polyacrylamide gel electrophoresis gel containing the same protein extracts as used in A and B (lower panels). showed that most genes (178) were annotated as "hypothetical proteins" in the T. cruzi GeneDB. We found mRNAs encoding proteins involved in RNA processing and transport, cytochrome B complex proteins and dyneinassociated proteins (Fig. 3, Supplementary data). Interestingly, the mRNA encoding the TcZFP2 protein was present in the pull-down fraction, suggesting that this protein may be regulating the expression of its own transcripts.

Several RBPs regulate their own transcripts through positive or negative feedback regulatory loops, which suggests that such autoregulatory mechanisms are characteristic of RBPs that are involved in controlling gene expression (Pullmann et al. 2007). Indeed, our results suggest that these mechanisms may be a conserved feature of RBPs in eukaryotes.

TcZFP2 binds an A-rich, short sequence in the 3'UTR of a target transcript - To confirm the RNA pull-down assay results, we conducted an EMSA using an RNA oligo

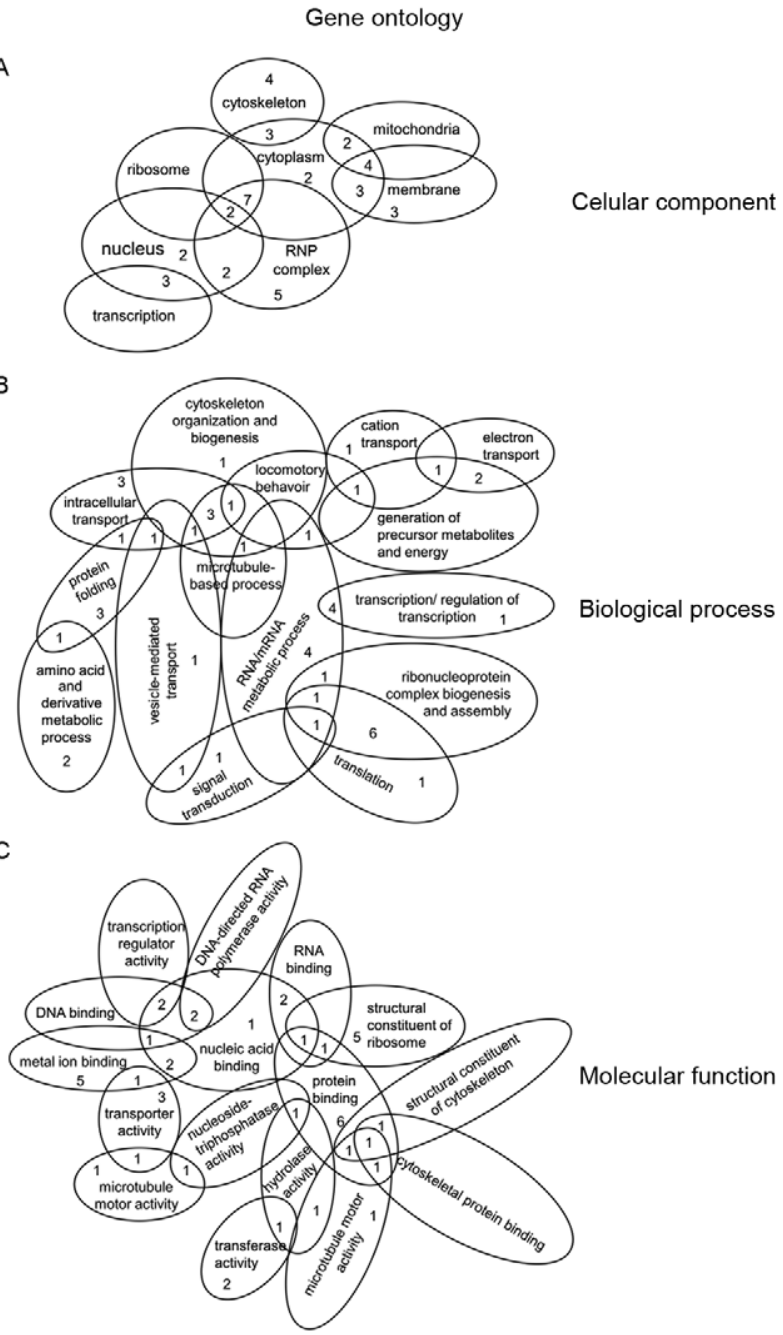

Fig. 3: gene ontology (GO) terms for the putative $T c Z F P 2$-regulated mRNAs. Venn diagram of overlaps between GO terms for the cellular components (A), molecular functions (B) and biological processes (C) of the annotated mRNAs bound by TcZFP2 in RNA immunopreciptation followed by microarray analysis assays. RNP: ribonucleoprotein particle. 
(TUTR) containing the first $64 \mathrm{nt}$ from the 3' UTR of the TcZFP2 mRNA as a probe (EST with GenBank accession CF889184.1) because this transcript was present in the pull-down fraction (Fig. 4A). The TcZFP2 recombinant protein formed a stable complex with the probe on EMSA (Fig. 4B, Lane 2). We subsequently conducted a more detailed analysis to identify the putative binding sequence of TcZFP2. Overlapping oligoribonucleotides spanning the entire putative UTR were synthesised and tested by EMSA (Fig. 4A). TcZFP2 formed a stable complex with the UTR4 probe (Fig. 4B, Lane 10). Competition assays using the TUTR as a probe and the five partial sequences

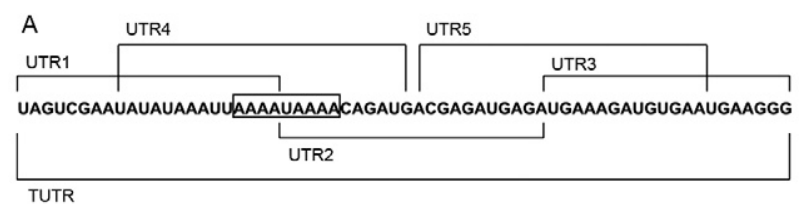

B

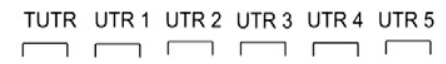

$\begin{array}{llllllllllll}1 & 2 & 3 & 4 & 5 & 6 & 7 & 8 & 9 & 10 & 11 & 12\end{array}$

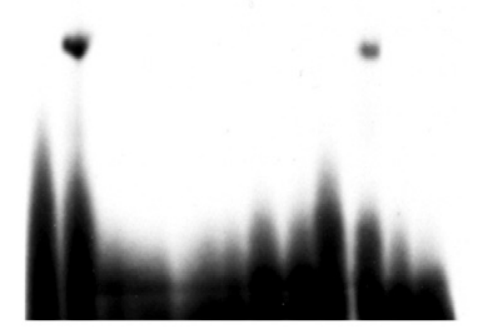

C

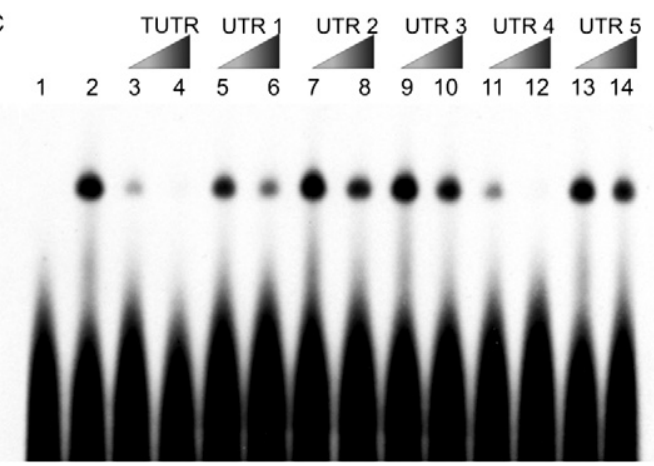

Fig. 4: the binding of TcZFP2 to the 3' untranslated region (UTR) of the TcZFP2 mRNA is highly sequence-specific. A: schematic diagram of the putative 3'UTR of the TcZFP2 mRNA. This region was used as a template for the synthesis of oligoribonucleotides for electrophoretic mobility shift assay, as shown. Boxed motif shows the putative binding site; B: gel mobility shift assay to assess binding capacity. Free radiolabelled probes are shown in Lanes 1, 3, 5, 7, 9 and 11. Binding reactions with $500 \mathrm{ng}$ of the recombinant TcZFP2 and $0.5 \mathrm{ng}$ of the corresponding labelled probe (approx. $10.000 \mathrm{cpm}$ ) are shown in Lanes $2,4,6,8,10$ and 12; C: specificity assays for the TUTR oligoribonucleotide. Effects on formation of the TcZFP2 + TUTR probe complex of a 1 (Lanes 3, 5, 7, 9, 11, 13) and 100-fold molar excess of unlabeled competitors (Lanes 4, 6, 8, 10, 12, 14). Free-labelled TUTR probe (Lane 1); Binding reaction for TcZFP2 + TUTR labelled probe (Lane 2). as unlabelled competitors showed that only the UTR4 probe abolished the formation of TcZFP2-RNA complexes (Fig. 4C, Lanes 11, 12). A certain degree of competition was observed when high concentrations of the unlabelled UTR1 competitor were tested (Fig. 4C, Lane 6).

Based on the competition pattern, an analysis of the probe sequence suggested that the putative recognition element might be an A-rich sequence $\left(\mathrm{A}_{1-4} \mathrm{UA}_{1-4}\right)$. We tested this hypothesis by synthesising oligoribonucleotide probes in which the central uridine base was replaced by a guanine (MUT1) (UAUAAAUUAAAAGAAAACAGAUG) or in which the central adenine residues of the quadruplet were replaced by cytosines (MUT2) (UAUAAUUACCAUACCACAGAUG). Binding assays revealed that $T c Z F P 2$ formed complexes with the UTR4 and MUT1 probes, yielding bands of similar intensities, whereas recognition of the MUT2 probe was less efficient (Fig. 5). We analysed the interaction between the recombinant TcZFP2 protein and the UTR4 and mutant probes in detail by studying the $\mathrm{K}_{\mathrm{d}}$ of the ribonucleoprotein complexes observed. The recombinant $T c Z F P 2$ recognised the UTR4 probe with an apparent $\mathrm{K}_{\mathrm{d}}$ of approximately 800 nM (Fig. 5A). Although TcZFP2 complexes were clearly formed at low protein concentrations, with both the UTR4 and the MUT1 probes (50 ng), quantitative binding affinity analysis revealed a two-fold difference in the affinities of the two probes. The $\mathrm{K}_{\mathrm{d}}$ values obtained for the MUT1 probe were similar to those obtained for a poly(A) probe ( 2.300 and $2.000 \mathrm{nM}$, respectively) (Fig. 5B, 5D), suggesting that $T c Z F P 2$ recognises A-rich sequences, albeit with a lower affinity. In contrast, the affinity obtained for the MUT2 probe was almost 10 times lower than that of the specific probe $\left(\mathrm{K}_{d} 8.300 \mathrm{nM}\right)$ (Fig. 5C).

Competition assays in which the complete UTR was used as a probe and the UTR4 and mutant oligomers were used as unlabelled competitors showed that the UTR4 and MUT1 probes competed efficiently (Fig. 6). We cannot exclude the possibility that TcZFP2 also recognises an RNA secondary structure, but our results strongly suggest that the target element is defined by the linear sequence. Competition assays using Mut2 showed that the A residues are essential for high-affinity binding. However, TcZFP2 also bound the A-rich Mut1 sequence with slightly lower affinity. These data provide valuable insight, but further comparative analysis of these sequences to the UTRs of other transcript targets is required to define the exact $T c Z F P 2$ recognition motif.

TbZFP2 genetic assays in T. Brucei - RNA interference was used to analyse changes in the levels of the TcZFP2-associated mRNAs and these assays were conducted using the $T$. brucei system because T. cruzi lacks the machinery required for RNA interference. Hence, the orthologous gene TbZFP2 was targeted by RNAi, with the assumption that there was conservation between the putative TCZFP2 targets of the two species.

When the TbZFP2 levels were analysed after RNAi, we noted considerable depletion of the TbZFP2 mRNA, although the leakiness of the tetracycline-inducible system was such that the uninduced cell lines exhibited comparable levels of ablation. Consistent with this, there were large decreases in TbZFP2 protein levels in both 
induced and uninduced samples (Fig. 7A). Therefore, comparisons within this experiment (Fig. 7) were conducted using the uninduced TbZFP2 cell line and the parental PTT procyclic cell line. When the abundances of the predicted TbZFP2 target transcripts were assayed by qPCR (with actin and TbPTP1 used as negative control transcripts), most abundances were considerably lower in response to reduced levels of TbZFP2 compared to the parental line (Fig. 7B).

In addition, the TbZFP2 protein was ectopically overexpressed with a C-terminal Ty1 tag. As before, levels of the putative TbZFP2-regulated transcripts were analysed by qRT-PCR, with actin and TbPTPI again used as negative control transcripts. The levels of mRNA for the putative target genes displayed no significant variations upon TbZFP2 ectopic overexpression (Fig. 8).

We looked for the presence of the $\mathrm{A}_{1-4} \mathrm{UA}_{1-4}$ element in the putative 3'UTRs of the T. brucei transcripts. All of the transcripts analysed contained the putative binding motif. These results suggest that TbZFP2 targets similar transcript pools to TcZFP2 and that TbZFP2 acts as a positive regulator, such that when it is depleted, the abundance of target mRNAs decreases.

TcZFP2 target $m R N A$ s are upregulated in infectious metacyclic forms - We analysed the expression profiles of the genes encoding the TcZFP2-associated mRNAs throughout the parasite life cycle by microarray hybridisation. Most of the associated mRNAs were upregulated in the metacyclic trypomastigote forms (Fig. 9), which suggests that TcZFP2 plays a role in metacyclic trypomastigote differentiation.

\section{DISCUSSION}

Over the last 10 years, major efforts have been devoted to the identification of the transcripts bound and regulated by RBPs and the characterisation of the gene regulatory networks controlled by them (Sanchez-Diaz \& Penalva 2006). The ribonomic approach is based on the genome-wide identification of mRNAs associated with RBPs (Tenenbaum et al. 2002). This approach has been used to identify the putative mRNA targets of the T. brucei PUF family (Luu et al. 2006) and an RRMtype protein (Estevez 2008). In T. cruzi, we have identified mRNAs associated with TcPUF6, which is an RBP of the PUF family, by TAP-TAG purification followed by microarray hybridisation (Dallagiovanna et al. 2008). Here, we used a modified version of the RIP-CHIP assay to identify the transcripts bound by TcZFP2. We simplified the assay by binding the recombinant protein directly to a Ni-NTA-agarose resin, overcoming the need for an immunoprecipitation step. This modification made it possible to identify the putative target transcripts forming complexes with TcZFP2.

It has been suggested that RBPs also regulate the function of the associated mRNAs in trypanosomes (Noé et

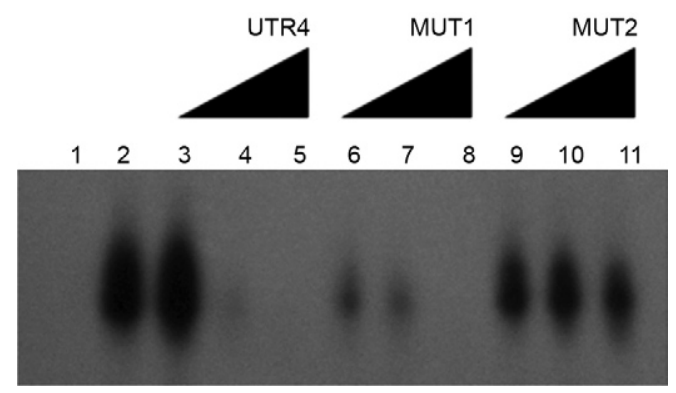

Fig. 6: competition assays with the mutated ribonucleotides. Lane 1: TUTR free radiolabelled probe (approx. $10.000 \mathrm{cpm}$ ); 2: binding reaction with $500 \mathrm{ng}$ of the recombinant TcZFP2; 3-5: untranslated region (UTR)4-ribonucleotide was added as an unlabelled competitor in a 1,10 or 100 -fold molar excess, respectively, and incubated at room temperature for $10 \mathrm{~min}$ prior to the addition of the labelled probe. Same with the MUT1 (Lanes 6-8) and MUT2-ribonucleotide (Lanes 9-11). Gels were pre-run at $200 \mathrm{~V}$ at $4^{\circ} \mathrm{C}$ and then run with the samples for $3-4 \mathrm{~h}$ at $250 \mathrm{~V}$ at $4^{\circ} \mathrm{C}$.
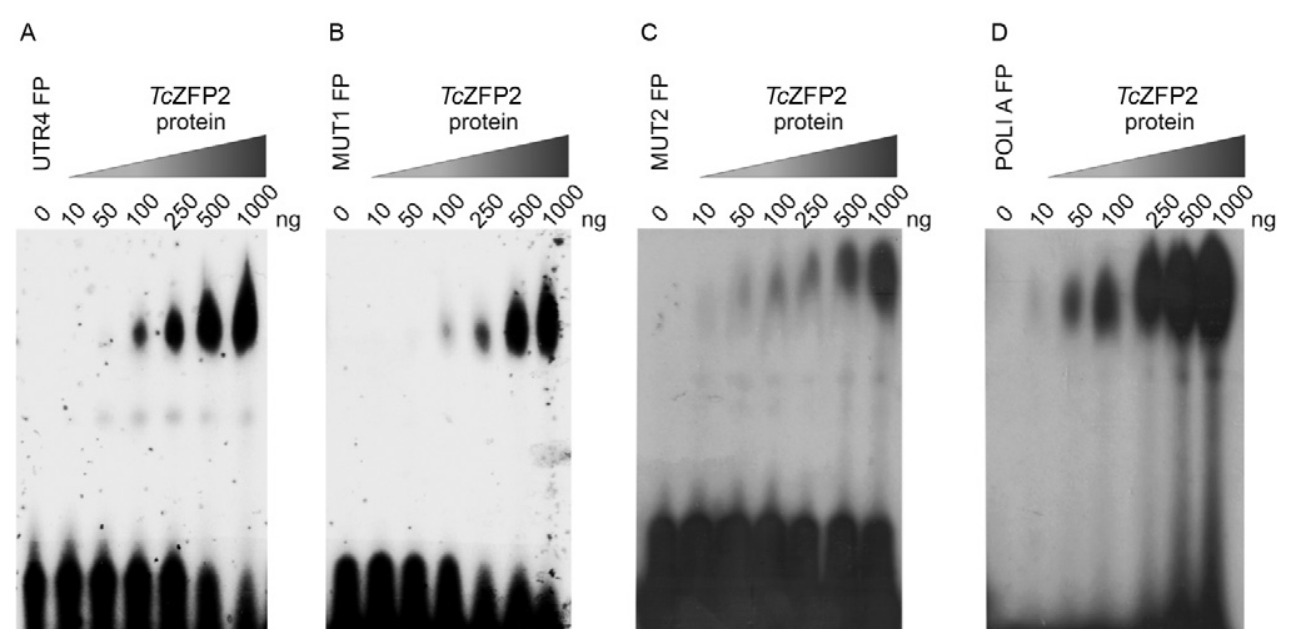

Fig. 5: affinity analysis of the complexes formed by the recombinant TcZFP2 and the oligoribonucleotides. Binding reactions with the untranslated region (UTR)4 (A), MUT1 (B), MUT2 (C) and POLI A (D) probes were carried out with various amounts of the recombinant TcZFP2 protein and $0.5 \mathrm{ng}$ of the labelled probe (approx. $10.000 \mathrm{cpm}$ ). Lanes: binding reactions with 10, 50, 100, 250, 500 and $1.000 \mathrm{ng}$ of protein, respectively. FP: free probe. 
al. 2008, Kabani et al. 2009, Ouellette \& Papadopoulou 2009). Therefore, we looked for functional relationships between the identified mRNAs. Most of the transcripts encoded hypothetical proteins, but some of these proteins were nuclear-encoded mitochondrial proteins, motor proteins or proteins involved in RNA transport. Interestingly, TcZFP2 bound its own transcript. Several RBPs regulate their own transcripts through positive or negative feedback regulatory loops. Pullmann et al. (2007) suggested that such autoregulatory mechanisms are characteristic of RBPs that are involved in controlling gene expression. Indeed, our results suggest that these mechanisms may be conserved features of RBPs in eukaryotes.

We defined the putative 3'UTR of the TcZFP2 transcript by searching the EST database. We subsequently used this sequence to confirm binding on EMSA. TcZFP2 was found to bind with high specificity to an Arich region in the 3'UTR sequence. We cannot exclude
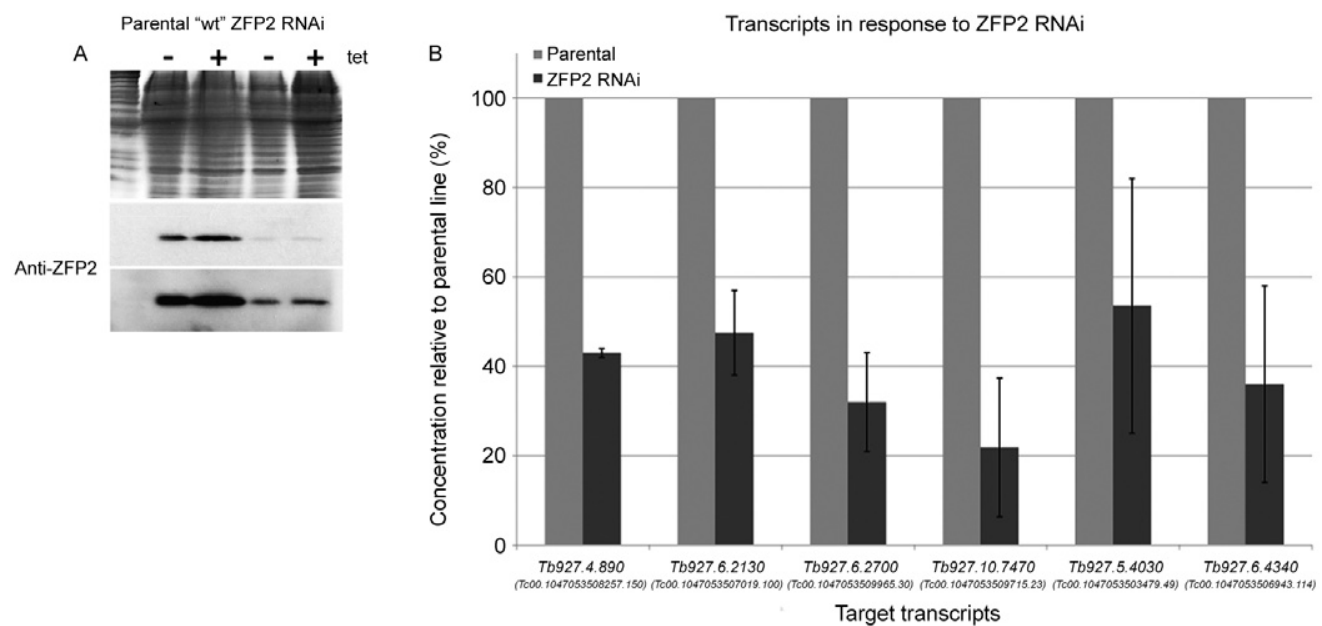

Fig. 7: TbZFP2 knockdown specifically reduces levels of putative targets. A: TbZFP2 protein levels in parental vs. tetracycline-induced or uninduced p2T7i-TbZFP2 PTT procyclic Trypanosoma brucei cells. The Coomassie-stained gel indicates relative loading, the middle image shows TbZFP2 protein levels and the lower image represents a longer exposure of the same blot. Since no dramatic change was observed in the levels of TbZFP2 in either cell line in response to tetracycline, total RNA was harvested from parental T. brucei PTT cells and p2T7i-TbZFP2 PTT procyclic cells, both in the absence of tetracycline; B: identities and relative concentrations of the syntenic T. brucei orthologs of the TcZFP2associating transcripts in response to reduced levels of TbZFP2. The concentrations represent the relative percentages of each transcript normalized to actin transcripts in each sample. Bars indicate standard deviation.
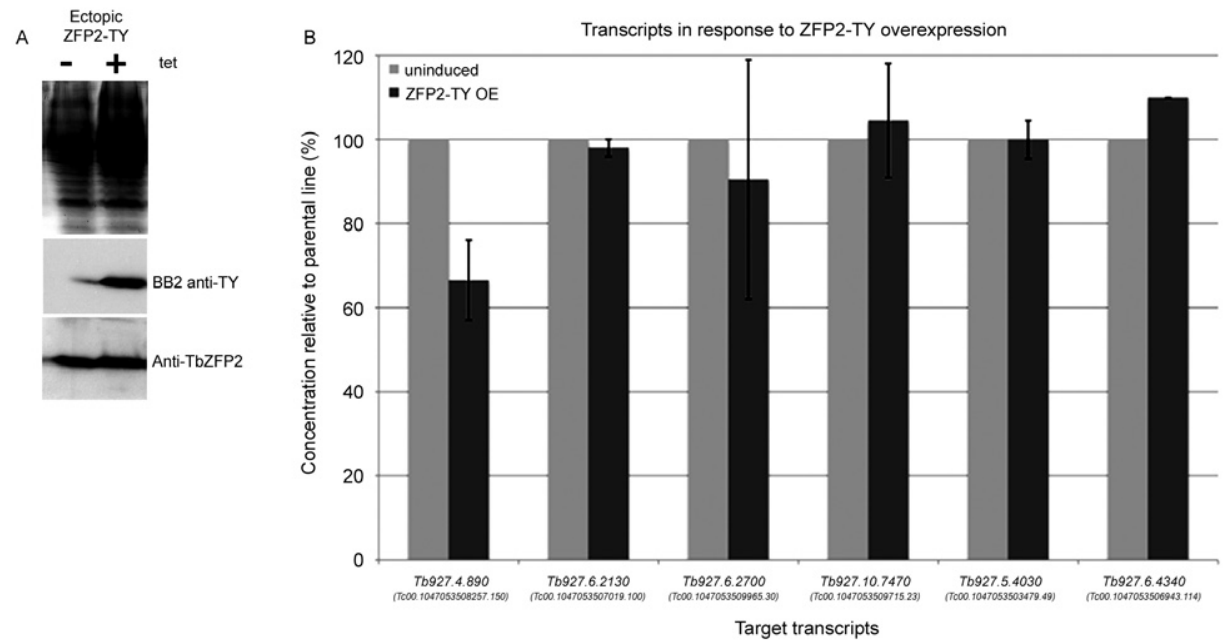

Fig. 8: Trypanosoma brucei transcript levels in response to TbZFP2 overexpression. A: TbZFP2 protein in uninduced vs. Tetracycline-induced pHD451-ZFP2-TY procyclic T. brucei cells. Coomassie-stained gel indicates relative loading. Upper film indicates relative ectopic TbZFP2-TY expression. BB2 monoclonal antibody recognizes the Ty1 motif [provided by Prof Keith Gull (Oxford)]. This antibody therefore recognizes only the ectopic TbZFP2-TY and allowed us to confirm the inducible overexpression of TbZFP2. Lower film indicates relative levels of endogenous TbZFP2. As demonstrated previously, anti-TbZFP2 antibody does not recognize TbZFP2-TY (Hendriks et al. 2001); B: identities and relative concentrations of $T$. brucei homologs of TcZFP2-associating transcripts in response to ectopic TbZFP2-TY induction. Concentrations represent relative percentages normalized to actin. Bars indicate standard deviation. 
the possibility that TcZFP2 also recognises an RNA secondary structure, but our results strongly suggest that the target element is defined by the linear sequence. Competition assays showed that the $U$ residue in the central position was essential for high-affinity binding. However, TcZFP2 also bound A-rich sequences with slightly lower affinity, thereby increasing the number of putative targets. Further analysis is required to define the exact recognition motif.
There is strong evidence to suggest that post-transcriptionally regulated operons exist in trypanosomatid parasites. Metabolically related genes display tight coregulation in trypanosomes (Mayho et al. 2006, Noé et al. 2008, Queiroz et al. 2009). Developmentally regulated RNA regulons have been identified in both $T$. brucei and T. cruzi (Dallagiovanna et al. 2008, Queiroz et al. 2009). Intriguingly, TcZFP2 levels are lower in metacyclic cells. This finding appears to be incompatible with

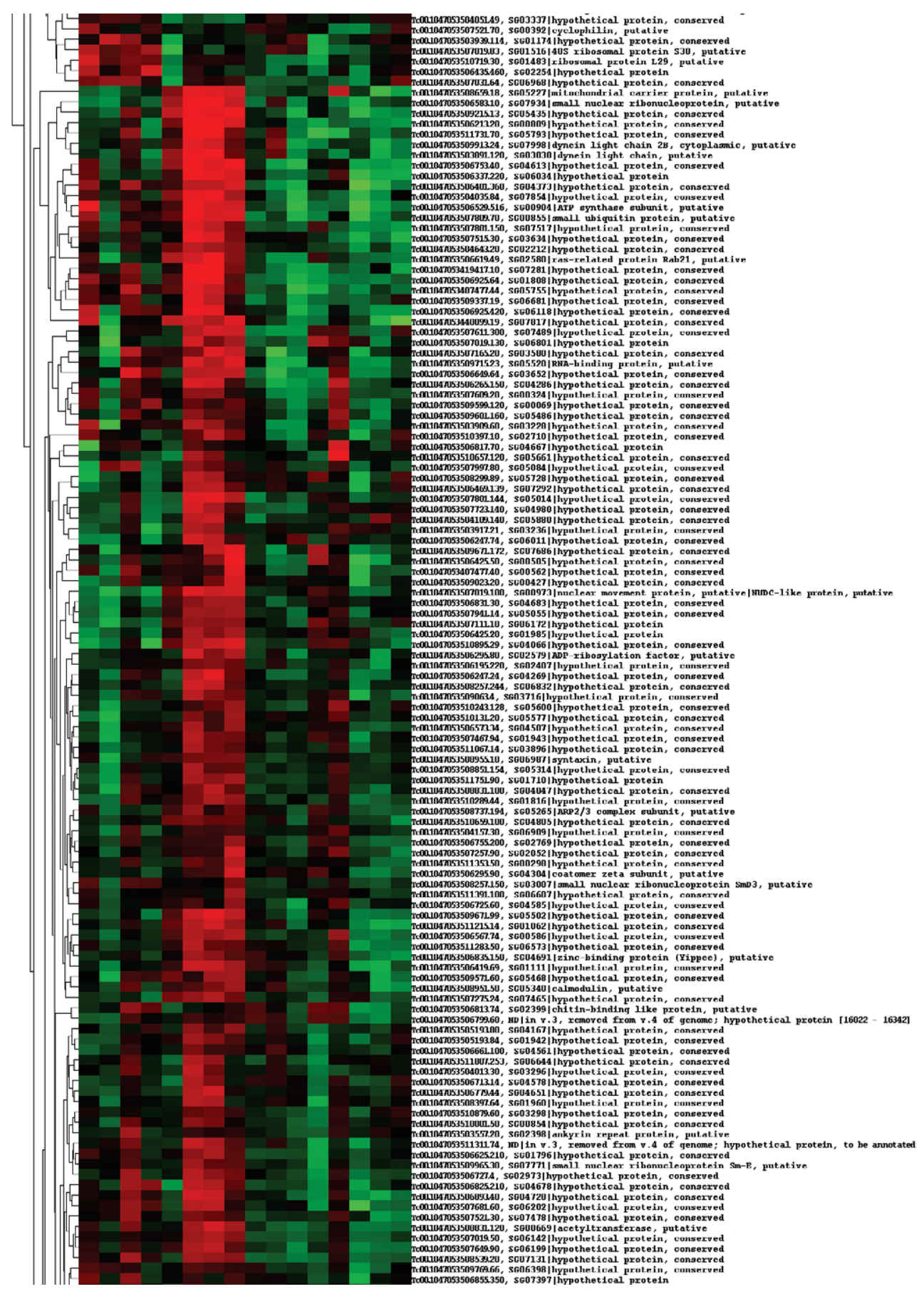

Fig. 9: TcZFP2-associated mRNAs are upregulated in metacyclic forms. Microarray analysis of the polysomal RNA fraction during differentiation showed that the mRNAs bound by TcZFP2 were produced preferentially in metacyclic forms. Each column represents an independent experiment. Ama: amastigotes forms; Epi: epimastigotes; Met: metacyclic trypomastigotes; Trp: cell-derived trypomastigotes. 
the mRNA-stabilising function proposed. RNA PolII activity has been observed to be much weaker in infectious forms (at least an order of magnitude lower than in non-infectious forms), which results in lower levels of total mRNA in the cell (Queiroz et al. 2009). Therefore, we can also assume that smaller amounts of the regulator protein are required to obtain a positive effect. Our data for T. brucei support this assumption because the TbZFP2 knockdown reduces the abundance of associating transcripts. The fact that overexpression does not significantly affect the same targets could simply indicate that the levels in the cell are sufficient to ensure mRNA stability. Hence, depletion decreases stability, but overexpression does not push stability beyond already maximal levels.

It is possible that TcZFP2 is in a competitive equilibrium with a putative negative regulator in epimastigotes. This negative regulator may be absent in metacyclic forms, resulting in the observed transcript stabilisation and upregulation. Another hypothesis is that TcZFP2 association with other protein complexes involving compartmentalisation or sequestration may be occurring during the metacyclic stage of T. cruzi. One clear example is T. cruzi PUF-6 (TcPUF6). In epimastigotes, TcPUF6 co-localises with the decapping activator TcDhh1, which supports the notion that TcPUF6 might target mRNAs for degradation. In contrast, TcPUF6 and TcDhh1 do not co-localise in metacyclic trypomastigote forms, which suggests the absence of interaction and, consequently, the upregulation of associated mRNAs in the metacyclic forms (Dallagiovanna et al. 2008).

Recently, a novel $\mathrm{CCCH}$ zinc finger protein $(T b Z C 3 \mathrm{H} 20)$ was shown to be enriched in insect procyclic forms of $T$. brucei and also to positively modulate the stability of its mRNA targets (Ling et al. 2011). The binding of the $T b Z C 3 \mathrm{H} 20$ to poly(A) or the recruitment of distinct components of the translational machinery are among the mechanisms suggested to avoid the degradation of target mRNA.

In $T$. brucei, the knockdown of the orthologous TbZFP2 abolishes differentiation into the circulating forms found in the bloodstream (Hendricks et al. 2001). In addition, the related TbZFP1 protein is also involved in controlling kinetoplast segregation; this protein has been shown to interact with other members of this protein family (Hendricks \& Matthews 2005, Paterou et al. 2006). Thus, one conserved function of these proteins in trypanosomes may be the regulation of kinetoplast segregation during differentiation. This phenotypic effect was dose-dependent, which reveals the need for a delicate protein balance to regulate the differentiation process. More recently, Walrad et al. (2011) performed a global survey of the mRNAs that co-associate with the TbZFP3 mRNP. The results showed that the selected mRNAs were stabilised by TbZFP3 and the associated transcripts were predominantly more abundant in the transmission stage of T. brucei for stumpy forms. This result implicates TbZFP3 mRNP as a trans-acting factor defining a regulon in these parasites, controlling the changes in gene expression that accompany the life-cycle development of the parasite. Together, these results demonstrate that ZFP2 and ZFP3 proteins have important roles in regulating trypanosome differentiation.

\section{ACKNOWLEDGEMENTS}

To Nilson Fidencio and Andreia Dallabonna, for technical assistance, and to Dr Alejandro Correa Dominguez and Mario Hüttner Queiroz, for critical reading of the manuscript.

\section{REFERENCES}

Auweter SD, Oberstrass FC, Allain FH 2006. Sequence-specific binding of single-stranded RNA: is there a code for recognition? Nucleic Acids Res 17: 4943-4959.

Ávila AR, Dallagiovanna B, Yamada-Ogatta SF, Monteiro-Góes V, Fragoso SP, Krieger MA, Goldenberg S 2003. Stage-specific gene expression during Trypanosoma cruzi metacyclogenesis. Genet Mol Res 2: 159-168.

Bonaldo MC, Souto-Padron T, de Souza W, Goldenberg S 1988. Cellsubstrate adhesion during Trypanosoma cruzi differentiation. J Cell Biol 106: 1349-1358.

Caro F, Bercovich N, Atorrasagasti C, Levin MJ, Vázquez MP 2005. Protein interactions within the TcZFP zinc finger family members of Trypanosoma cruzi: implications for their functions. Biochem Bioph Res Com 333: 1017-1025.

Cassola A, de Gaudenzi JG, Frasch AC 2007. Recruitment of mRNAs to cytoplasmic ribonucleoprotein granules in trypanosomes. Mol Microbiol 65: 655-670.

Clayton C, Shapira M 2007. Post-transcriptional regulation of gene expression in trypanosomes and leishmanias. Mol Biochem Parasitol 156: 93-101.

Contreras VT, Araújo-Jorge TC, Bonaldo MC, Thomas N, Barbosa HS, Meirelles MNSL, Goldenberg S 1988. Biological aspects of the DM 28c clone of Trypanosoma cruzi after metacyclogenesis in chemically defined media. Mem Inst Oswaldo Cruz 83: 123-133.

Contreras VT, Salles JM, Thomas N, Morel CM, Goldenberg S 1985. In vitro differentiation of Trypanosoma cruzi under chemically defined conditions. Mol Biochem Parasitol 16: 315-327.

D’Orso I, de Gaudenzi J, Frasch AC 2003. RNA-binding proteins and mRNA turnover in trypanosomes. Trends Parasitol 19: 151-155.

Dallagiovanna B, Correa A, Probst CM, Holetz F, Smircich P, Aguiar AM, Mansur F, da Silva CV, Mortara RA, Garat B, Buck GA, Goldenberg S, Krieger MA 2008. Functional genomic characterization of mRNAs associated with TcPUF6, a Pumilio-like protein from Trypanosoma cruzi. J Biol Chem 283: 8266-8273.

de Souza W 2002. Basic cell biology of Trypanosoma cruzi. Curr Pharm 8: 269-285.

Estevez AM 2008. The RNA-binding protein TbDRBD3 regulates the stability of a specific subset of mRNAs in trypanosomes. $\mathrm{Nucl}$ Acids Res 36: 4573-4586.

Haile SDA, Papadopoulou B 2008. Deadenylation-independent stage-specific mRNA degradation in Leishmania. Nucleic Acids Res 5: 1634-1644.

Hendricks EF, Matthews KR 2005. Disruption of the developmental programme of Trypanosoma brucei by genetic ablation of TbZFP1, a differentiation-enriched $\mathrm{CCCH}$ protein. Mol Microbiol 57: 706-716.

Hendricks EF, Matthews KR 2007. Post-transcriptional control of gene expression in African trypanosomes. In D Barry, R McCulloch, J Mottram, A Acosta-Serrano, Trypanosomes: after the genome, Horizon Bioscience, Norwich, p. 209-237. 
Hendricks EF, Robinson DR, Hinkins M, Matthews KR 2001. A novel $\mathrm{CCCH}$ protein which modulates differentiation of Trypanosoma brucei to its procyclic form. EMBO J 20: 1-12.

Holetz F, Correa A, Avila AR, Nakamura CV, Krieger MA, Goldenberg S 2007. Evidence of P-body-like structures in Trypanosoma cruzi. Biochem Bioph Res Com 356: 1062-1067.

Kabani S, Fenn K, Ross A, Ivens A, Smith TK, Ghazal P, Matthews $\mathrm{K}$ 2009. Genome-wide expression profiling of in vivo-derived bloodstream parasite stages and dynamic analysis of mRNA alterations during synchronous differentiation in Trypanosoma brucei. BMC Genomics 10: 427.

Kramer S, Kimblin NC, Carrington M 2010. Genome-wide in silico screen for $\mathrm{CCCH}$-type zinc finger proteins of Trypanosoma brucei, Trypanosoma cruzi and Leishmania major. BMC Genomics 11: 283.

Ling AS, Trotter JR, Hendriks EF 2011. A zinc finger protein, TbZC 3H20, stabilizes two developmentally regulated mRNAs in trypanosomes. J Biol Chem 286: 20152-20162.

Lunde BM, Moore C, Varani G 2007. RNA-binding proteins: modular design for efficient function. Nat Rev Mol Cell Biol 6: 479-490.

Luu VD, Brems S, Hoheisel JD, Burchmore R, Guilbride DL, Clayton C 2006. Functional analysis of Trypanosoma brucei PUF1. Mol Biochem Parasitol 2: 340-349.

Mayho M, Fenn K, Craddy P, Crosthwaite S, Matthews K 2006. Posttranscriptional control of nuclear-encoded cytochrome oxidase subunits in Trypanosoma brucei: evidence for genome-wide conservation of life-cycle stage-specific regulatory elements. Nucleic Acids Res 34: 5312-5324.

Mörking PA, Dallagiovanna BM, Foti L, Garat B, Picchi GFA, Umaki ACS, Probst CM, Krieger MA, Goldenberg S, Fragoso SP 2004. TcZFP1: a CCCH zinc finger protein of Trypanosoma cruzi that binds poly-C oligoribonucleotides in vitro. Biochem Bioph Res Com 319: 169-177.

Nardelli SC, Avila AR, Freund A, Motta MC, Manhaes L, Jesus TCL, Schenkman S, Fragoso SP, Krieger MA, Goldenberg S, Dallagiovanna B 2006. Small-subunit rRNA processome proteins are translationally regulated during differentiation of Trypanosoma cruzi. Eukaryot Cell 6: 337-345.
Noé G, de Gaudenzi JG, Frasch AC 2008. Functionally related transcripts have common RNA motifs for specific RNA-binding proteins in trypanosomes. BMC Mol Biol 9: 107.

Ouellette M, Papadopoulou B 2009. Coordinated gene expression by post-transcriptional regulons in African trypanosomes. J Biol 8: 100.

Paterou A, Walrad P, Craddy P, Fenn K, Matthews K 2006. Identification and stage-specific association with the translational apparatus of $T b Z F P 3$, a CCCH protein that promotes trypanosome life-cycle development. J Biol Chem 281: 39002-39013.

Pullmann R Jr, Kim HH, Abdelmohsen K, Lal A, Martindale JL, Yang X, Gorospe M 2007. Analysis of turnover and translation regulatory RBP expression through binding to cognate mRNAs. Mol Cell Biol 27: 6265-6278.

Queiroz R, Benz C, Fellenberg K, Hoheisel JD, Clayton C 2009. Transcriptome analysis of differentiating trypanosomes reveals the existence of multiple post-transcriptional regulons. $B M C G e$ nomics 10: 495.

Sanchez-Diaz P, Penalva LO 2006. Post-transcription meets postgenomic: the saga of RNA binding proteins in a new era. RNA Biol 3: 101-109.

Smyth GK 2004. Linear models and empirical Bayes methods for assessing differential expression in microarray experiments. Stat Appl Genet Mol Biol 3: 3.

Tenenbaum SA, Lager PJ, Carson CC, Keene JD 2002. Ribonomics: identifying mRNA subsets in mRNP complexes using antibodies to RNA-binding proteins and genomic arrays. Methods 26: 191-198.

Townley-Tilson WH, Pendergrass SA, Marzluff WF, Whitfield ML 2006. Genome-wide analysis of mRNAs bound to the histone stem-loop binding protein. RNA 10: 1853-1867.

Walrad P, Paterou A, Acosta-Serrano A, Matthews KR 2009. Differential trypanosome surface coat regulation by a $\mathrm{CCCH}$ protein that co-associates with procyclin mRNA cis-elements. Plos Pathog 5: 1-10.

Walrad PB, Capewel P, Fenn K, Matthews KR 2011. The post-transcriptional trans-acting regulator, TbZFP3, co-ordinates transmission-stage enriched mRNAs in Trypanosoma brucei. Nucleic Acids Res 39: 1-15. 
Oligoribonucleotides used for electrophoretic mobility shift assay

\begin{tabular}{lc}
\hline $\begin{array}{l}\text { Primer } \\
\text { designation }\end{array}$ & $\begin{array}{c}\text { Nucleotide sequence } \\
\left(5 '-\ldots . .-3^{\prime}\right)\end{array}$ \\
\hline TUTR & $\begin{array}{c}\text { UAGUCGAAUAUAUAAAUUAAAAUA } \\
\text { AAACAGAUGACGAGAUGAGAUGAA } \\
\text { AGAUGUGAAUGAAGGG }\end{array}$ \\
UTR1 & UAGUCGAAUAUAUAAAUUAAAA \\
UTR2 & UAAAACAGAUGACGAGAUGAGA \\
UTR3 & UGAAAGAUGUGAAUGAAGGG \\
UTR4 & UAUAAAUUAAAAUAAAACAGAUG \\
UTR5 & ACGAGAUGAGAUGAAAGAUGUG \\
MUT1 & UAUAAAUUAAAAGAAAACAGAUG \\
MUT2 & UAUAAAUUACCAUACCACAGAUG
\end{tabular}

UTR: untranslated region.

Oligonucleotides used for quantitative real time-polymerase chain reaction

\begin{tabular}{|c|c|}
\hline $\begin{array}{l}\text { Trypanosoma brucei } \\
\text { gene ID }\end{array}$ & $\begin{array}{l}\text { Nucleotide sequence } \\
\left.\qquad(5,-\ldots . .-3)^{\prime}\right)\end{array}$ \\
\hline$T b 927.4 .890$ & $\begin{array}{l}\text { ATGGGCGTGTTACTGACCTC } \\
\text { TTCTTTGGCTTCTTACGGGA }\end{array}$ \\
\hline Tb927.10.15150 & $\begin{array}{c}\text { TGCAATCGTTTCTCATGCTC } \\
\text { CACTGGAAGCCACACTTCAAAC }\end{array}$ \\
\hline$T b 927.6 .2130$ & $\begin{array}{l}\text { AGGCATGAAGGGTCAATCAC } \\
\text { CGGAGATATGTTTGCTCGGTG }\end{array}$ \\
\hline$T b 927.6 .2700$ & $\begin{array}{l}\text { TTAAGCCGACTGTTGTCGTG3 } \\
\text { TGCCAATAGGGTGAATGACAC }\end{array}$ \\
\hline$T b 927.10 .7470$ & $\begin{array}{l}\text { GCGAATTCTCCTTGTAACGG } \\
\text { CTAGCGCCCTACGATCTCTG }\end{array}$ \\
\hline$T b 927.5 .4030$ & $\begin{array}{c}\text { TGGATCGTCGTGTTGTTGTTTC } \\
\text { GGGTTCTGTTGAAGGATTGC }\end{array}$ \\
\hline$T b 927.6 .4340$ & $\begin{array}{l}\text { GTTTCCTTTCCTTCTTGGGT } \\
\text { TGGACACAACTGTCTGCCTC }\end{array}$ \\
\hline
\end{tabular}


TcZFP2 associated transcripts identified in the recombinant $t$ RNA immunopreciptation followed by microarray analysis assay

\begin{tabular}{|c|c|c|}
\hline Gene & Description & $\mathrm{FC}$ \\
\hline Tc00.1047053505807.29 & Hypothetical protein, conserved & 4,515 \\
\hline Тc00.1047053506825.210 & Hypothetical protein, conserved & 4,360 \\
\hline $\mathrm{Tc} 00.1047053507957 .140$ & Trans-sialidase (pseudogene), putative & 4,282 \\
\hline $\mathrm{Tc} 00.1047053507165 .20$ & Hypothetical protein, conserved & 4,239 \\
\hline Tc00.1047053504069.110 & Hypothetical protein, conserved & 3,729 \\
\hline Тc00.1047053509055.54 & Hypothetical protein, conserved & 3,670 \\
\hline Тc00.1047053505193.80 & Hypothetical protein, conserved & 3,610 \\
\hline Тc00.1047053504625.74 & Hypothetical protein, conserved & 3,568 \\
\hline Tc00.1047053506213.20 & Hypothetical protein, conserved & 3,512 \\
\hline Tc00.1047053506529.516 & ATP synthase subunit, putative & 3,464 \\
\hline Тc00.1047053506893.40 & Hypothetical protein, conserved & 3,429 \\
\hline Тc00.1047053506691.64 & Cytochrome $\mathrm{C}$ oxidase copper chaperone, putative & 3,425 \\
\hline Тc00.1047053507163.90 & Hypothetical protein, conserved & 3,371 \\
\hline Тc00.1047053503925.90 & Hypothetical protein, conserved & 3,353 \\
\hline Тc00.1047053504001.20 & Hypothetical protein, conserved & 3,287 \\
\hline $\mathrm{Tc} 00.1047053508831 .120$ & Acetyltransferase, putative & 3,264 \\
\hline Тc00.1047053509599.120 & Hypothetical protein, conserved & 3,260 \\
\hline Тc00.1047053511807.253 & Hypothetical protein, conserved & 3,246 \\
\hline Тc00.1047053506753.40 & Hypothetical protein, conserved & 3,226 \\
\hline $\mathrm{Tc} 00.1047053506925 .120$ & Eukaryotic initiation factor $5 \mathrm{a}$, putative & 3,201 \\
\hline Tc00.1047053506265.150 & Hypothetical protein, conserved & 3,195 \\
\hline Тc00.1047053508299.89 & Hypothetical protein, conserved & 3,175 \\
\hline Тc00.1047053506943.114 & U6 snrna-associated Sm-like protein LSm5p & 3,165 \\
\hline $\mathrm{Tc} 00.1047053508231 .64$ & Hypothetical protein, conserved & 3,082 \\
\hline Тc00.1047053401469.10 & Zinc finger protein 2 , putative & 3,080 \\
\hline Тc00.1047053509671.172 & Hypothetical protein, conserved & 3,078 \\
\hline Тc00.1047053510397.10 & Hypothetical protein, conserved & 3,076 \\
\hline Тc00.1047053506883.69 & Hypothetical protein, conserved & 3,067 \\
\hline Тc00.1047053503891.54 & Nucleolar RNA-binding protein, putative & 3,064 \\
\hline $\mathrm{Tc} 00.1047053507019 .100$ & Nuclear movement protein, putative & 3,045 \\
\hline Tc00.1047053507801.144 & Hypothetical protein, conserved & 3,031 \\
\hline Tc00.1047053507521.44 & Hypothetical protein, conserved & 2,992 \\
\hline Тc00.1047053507611.300 & Hypothetical protein, conserved & 2,989 \\
\hline Tc00.1047053506779.44 & Hypothetical protein, conserved & 2,959 \\
\hline Tc00.1047053506583.10 & Small nuclear ribonucleoprotein, putative & 2,959 \\
\hline Tc00.1047053503479.49 & U6 snRNA-associated Sm-like protein LSm7p & 2,953 \\
\hline Тc00.1047053508153.994 & Cytochrome $\mathrm{C}$ oxidase copper chaperone, putative & 2,950 \\
\hline Tc00.1047053506945.200 & Mago nashi-like protein, putative & 2,925 \\
\hline Тc00.1047053507019.130 & Hypothetical protein & 2,922 \\
\hline Тc00.1047053506831.30 & Hypothetical protein, conserved & 2,896 \\
\hline Tc00.1047053506337.220 & Hypothetical protein & 2,887 \\
\hline $\mathrm{Tc} 00.1047053509715 .23$ & RNA-binding protein, putative & 2,877 \\
\hline $\mathrm{Tc} 00.1047053507723 .140$ & Hypothetical protein, conserved & 2,844 \\
\hline Tc00.1047053419417.10 & Hypothetical protein, conserved & 2,842 \\
\hline Tc00.1047053506401.360 & Hypothetical protein, conserved & 2,842 \\
\hline $\mathrm{Tc} 00.1047053508737 .194$ & ARP2/3 complex subunit, putative & 2,832 \\
\hline $\mathrm{Tc} 00.1047053508851 .154$ & Hypothetical protein, conserved & 2,809 \\
\hline Тc00.1047053506925.64 & Hypothetical protein, conserved & 2,795 \\
\hline Тc00.1047053508817.160 & Trichohyalin, putative & 2,776 \\
\hline Tc00.1047053503425.20 & Glutaredoxin-like protein, putative & 2,771 \\
\hline $\mathrm{Tc} 00.1047053507625 .186$ & Hypothetical protein, conserved & 2,769 \\
\hline Тc00.1047053506247.24 & Hypothetical protein, conserved & 2,764 \\
\hline
\end{tabular}




\begin{tabular}{|c|c|c|}
\hline Gene & Description & FC \\
\hline Тc00.1047053504109.174 & Hypothetical protein, conserved & 2,764 \\
\hline Тс 00.1047053506363 .40 & Hypothetical protein, conserved & 2,751 \\
\hline Тс00.1047053506713.14 & Hypothetical protein, conserved & 2,746 \\
\hline Тc00.1047053506813.74 & Chitin-binding like protein, putative & 2,742 \\
\hline Тc00.1047053509215.13 & Hypothetical protein, conserved & 2,742 \\
\hline Tc00.1047053505193.84 & Hypothetical protein, conserved & 2,740 \\
\hline Tc00.1047053506567.74 & Hypothetical protein, conserved & 2,723 \\
\hline Тc00.1047053407477.40 & Hypothetical protein, conserved & 2,709 \\
\hline Тc00.1047053504157.30 & Hypothetical protein, conserved & 2,698 \\
\hline Тc00.1047053507801.150 & Hypothetical protein, conserved & 2,676 \\
\hline Тс00.1047053506817.70 & Hypothetical protein & 2,675 \\
\hline Тc00.1047053506755.200 & Hypothetical protein, conserved & 2,669 \\
\hline Тc00.1047053507991.129 & Cyclophilin, putative & 2,656 \\
\hline Тс00.1047053506649.64 & Hypothetical protein, conserved & 2,654 \\
\hline Тc00.1047053506425.50 & Hypothetical protein, conserved & 2,648 \\
\hline Тc00.1047053504035.84 & Hypothetical protein, conserved & 2,624 \\
\hline Тc00.1047053506295.80 & ADP-ribosylation factor, putative & 2,622 \\
\hline Тc00.1047053509693.194 & Hypothetical protein, conserved & 2,607 \\
\hline Тc00.1047053507949.69 & Hypothetical protein, conserved & 2,606 \\
\hline Тc00.1047053508897.100 & Dynein light chain, putative & 2,602 \\
\hline Тc00.1047053509671.99 & Hypothetical protein, conserved & 2,592 \\
\hline Тc00.1047053507521.30 & Hypothetical protein, conserved & 2,583 \\
\hline Тc00.1047053507941.14 & Hypothetical protein, conserved & 2,579 \\
\hline Tc00.1047053509011.54 & Ubiquinol-cytochrome $\mathrm{C}$ reductase, putative & 2,576 \\
\hline Tc00.1047053508659.18 & Mitochondrial carrier protein, putative & 2,573 \\
\hline Тc00.1047053506573.34 & Hypothetical protein, conserved & 2,567 \\
\hline Тc00.1047053511865.54 & Protein transport protein Sec61 gamma subunit, putative & 2,566 \\
\hline Тc00.1047053506625.210 & Hypothetical protein, conserved & 2,561 \\
\hline Тc00.1047053510879.60 & Hypothetical protein, conserved & 2,561 \\
\hline Tc00.1047053508257.150 & Small nuclear ribonucleoprotein $\mathrm{SmD} 3$, putative & 2,552 \\
\hline Тc 00.1047053506925 .460 & Hypothetical protein, conserved & 2,550 \\
\hline Тc00.1047053510731.104 & Hypothetical protein, conserved & 2,536 \\
\hline Тc00.1047053508503.30 & Hypothetical protein & 2,528 \\
\hline Тc00.1047053507019.50 & Hypothetical protein, conserved & 2,528 \\
\hline Тc00.1047053510243.128 & Hypothetical protein, conserved & 2,522 \\
\hline Tc00.1047053510609.34 & Hypothetical protein, conserved & 2,521 \\
\hline Тc00.1047053506363.10 & Hypothetical protein & 2,519 \\
\hline Tc00.1047053510657.120 & Hypothetical protein, conserved & 2,516 \\
\hline Тc00.1047053506469.139 & Hypothetical protein, conserved & 2,513 \\
\hline Тc00.1047053511291.120 & RNA polymerase III C11 subunit, putative & 2,505 \\
\hline Тc00.1047053509913.24 & Dynein light chain $2 \mathrm{~B}$, cytoplasmic, putative & 2,484 \\
\hline Тc00.1047053503917.21 & Hypothetical protein, conserved & 2,482 \\
\hline Tc00.1047053503891.120 & Dynein light chain, putative & 2,477 \\
\hline Тc00.1047053510131.20 & Hypothetical protein, conserved & 2,473 \\
\hline Tc00.1047053511211.104 & Hypothetical protein, conserved & 2,472 \\
\hline Тc00.1047053509055.60 & Hypothetical protein, conserved & 2,467 \\
\hline Тc00.1047053509769.66 & Hypothetical protein, conserved & 2,464 \\
\hline Тc00.1047053508257.244 & Hypothetical protein, conserved & 2,460 \\
\hline Тc00.1047053511283.194 & Hypothetical protein, conserved & 2,458 \\
\hline Тc00.1047053511003.180 & Hypothetical protein, conserved & 2,457 \\
\hline Tc00.1047053508257.204 & Hypothetical protein, conserved & 2,438 \\
\hline Тc00.1047053508307.150 & Hypothetical protein, conserved & 2,435 \\
\hline Тc00.1047053509337.19 & Hypothetical protein, conserved & 2,435 \\
\hline Тc00.1047053504013.30 & Hypothetical protein, conserved & 2,431 \\
\hline
\end{tabular}




\begin{tabular}{|c|c|c|}
\hline Gene & Description & $\mathrm{FC}$ \\
\hline Тc00.1047053509063.4 & Hypothetical protein, conserved & 2,420 \\
\hline Тc 00.1047053506855 .350 & Hypothetical protein & 2,408 \\
\hline Тc00.1047053507515.30 & Hypothetical protein, conserved & 2,395 \\
\hline Тc00.1047053508397.64 & Hypothetical protein, conserved & 2,387 \\
\hline Тc00.1047053511353.50 & Hypothetical protein, conserved & 2,383 \\
\hline Тc00.1047053510761.73 & Dynein-associated protein, putative & 2,380 \\
\hline Тc00.1047053509571.60 & Hypothetical protein, conserved & 2,375 \\
\hline Тc00.1047053506885.300 & Hypothetical protein, conserved & 2,367 \\
\hline Тc00.1047053506661.100 & Hypothetical protein, conserved & 2,366 \\
\hline Тc00.1047053506223.130 & Hypothetical protein, conserved & 2,366 \\
\hline Тc00.1047053506425.20 & Hypothetical protein & 2,363 \\
\hline Тc00.1047053503865.30 & Hypothetical protein, conserved & 2,359 \\
\hline Тc00.1047053510719.30 & Ribosomal protein L29, putative & 2,356 \\
\hline Тc00.1047053507775.40 & Hypothetical protein, conserved & 2,354 \\
\hline Тc00.1047053507873.34 & Hypothetical protein, conserved & 2,351 \\
\hline Тc00.1047053505555.20 & Hypothetical protein, conserved & 2,350 \\
\hline Тc00.1047053511731.70 & Hypothetical protein, conserved & 2,347 \\
\hline Тc00.1047053508851.150 & Hypothetical protein, conserved & 2,346 \\
\hline Тc00.1047053511003.170 & Hypothetical protein, conserved & 2,345 \\
\hline Тс00.1047053507809.70 & Small ubiquitin protein, putative & 2,330 \\
\hline Тc00.1047053511311.74 & $\begin{array}{l}\text { In v.3, removed from v. } 4 \text { of genome; } \\
\text { hypothetical protein, to be annotated } \\
\text { (newly added gene) (36855-36601) }\end{array}$ & 2,329 \\
\hline Тс 00.1047053509063 .20 & Hypothetical protein, conserved & 2,322 \\
\hline Тc00.1047053509023.20 & Hypothetical protein, conserved & 2,311 \\
\hline Тc00.1047053508153.634 & Hypothetical protein, conserved & 2,309 \\
\hline Тc00.1047053506529.30 & Hypothetical protein, conserved & 2,308 \\
\hline Тc00.1047053504109.140 & Hypothetical protein, conserved & 2,306 \\
\hline Тc00.1047053506223.90 & Hypothetical protein, conserved & 2,304 \\
\hline Тc00.1047053508539.20 & Hypothetical protein, conserved & 2,304 \\
\hline Тc00.1047053510001.50 & Hypothetical protein, conserved & 2,297 \\
\hline Tc00.1047053503557.20 & Ankyrin repeat protein, putative & 2,293 \\
\hline Тc00.1047053507257.30 & Hypothetical protein, conserved & 2,289 \\
\hline Tc00.1047053506977.49 & Ribosomal proteins L36, putative & 2,283 \\
\hline Тc00.1047053507467.94 & Hypothetical protein, conserved & 2,281 \\
\hline Тc00.1047053506727.150 & Hypothetical protein, conserved & 2,281 \\
\hline Тc00.1047053507611.280 & Cytochrome C oxidase subunit IX, putative & 2,270 \\
\hline Тc00.1047053506195.220 & Hypothetical protein, conserved & 2,258 \\
\hline Тc00.1047053506247.350 & Hypothetical protein, conserved & 2,248 \\
\hline Тc00.1047053504109.24 & Dynein light chain, putative & 2,246 \\
\hline Тc00.1047053506863.4 & Dephospho-CoA kinase, putative & 2,245 \\
\hline Тc00.1047053503939.114 & Hypothetical protein, conserved & 2,241 \\
\hline Тc00.1047053506625.140 & Hypothetical protein, conserved & 2,236 \\
\hline Тc00.1047053506419.69 & Hypothetical protein, conserved & 2,234 \\
\hline Тc00.1047053508323.84 & Peptidyl-prolyl cis-trans isomerase, putative & 2,223 \\
\hline Тc00.1047053511575.90 & Hypothetical protein & 2,222 \\
\hline Тc00.1047053506943.90 & Hypothetical protein, conserved & 2,220 \\
\hline Тc00.1047053503525.10 & Hypothetical protein, conserved & 2,213 \\
\hline Тc00.1047053507111.10 & Hypothetical protein & 2,213 \\
\hline Тc00.1047053511283.50 & Hypothetical protein, conserved & 2,209 \\
\hline Тc00.1047053508209.159 & Hypothetical protein, conserved & 2,201 \\
\hline Тc00.1047053503527.50 & Hypothetical protein, conserved & 2,200 \\
\hline Тc00.1047053506799.60 & $\begin{array}{l}\text { In v.3, removed from v. } 4 \text { of genome; } \\
\text { hypothetical protein }(16022-16342)\end{array}$ & 2,198 \\
\hline
\end{tabular}




\begin{tabular}{|c|c|c|}
\hline Gene & Description & $\mathrm{FC}$ \\
\hline Tc00.1047053508461.380 & Calmodulin, putative & 2,196 \\
\hline Tc00.1047053504073.20 & Hypothetical protein, conserved & 2,196 \\
\hline Tc00.1047053510659.100 & Hypothetical protein, conserved & 2,190 \\
\hline Тc00.1047053505171.44 & Hypothetical protein, conserved & 2,187 \\
\hline Tc00.1047053506473.6 & Hypothetical protein, conserved & 2,186 \\
\hline Тc00.1047053511751.90 & Hypothetical protein & 2,183 \\
\hline Тc00.1047053407477.44 & Hypothetical protein, conserved & 2,181 \\
\hline Тc00.1047053507257.90 & Hypothetical protein, conserved & 2,179 \\
\hline Тc00.1047053503999.70 & Ras-family member, GTP-binding protein, putative & 2,175 \\
\hline Тc00.1047053472777.9 & Hypothetical protein, conserved & 2,173 \\
\hline Tc00.1047053511067.14 & Hypothetical protein, conserved & 2,171 \\
\hline Тc00.1047053507993.89 & Hypothetical protein, conserved & 2,166 \\
\hline Tc00.1047053504109.180 & Hypothetical protein, conserved & 2,160 \\
\hline $\mathrm{Tc} 00.1047053508461 .480$ & 60 S ribosomal protein L23, putative & 2,155 \\
\hline Tc00.1047053504741.10 & Hypothetical protein, conserved & 2,155 \\
\hline Tc00.1047053511391.100 & Hypothetical protein, conserved & 2,152 \\
\hline Tc00.1047053507023.270 & Hypothetical protein, conserved & 2,150 \\
\hline Tc00.1047053510895.29 & Hypothetical protein, conserved & 2,147 \\
\hline Тc00.1047053509599.100 & Hypothetical protein & 2,145 \\
\hline $\mathrm{Tc} 00.1047053503929 .20$ & Ribosomal protein L13, putative & 2,142 \\
\hline Тc00.1047053509965.30 & Small nuclear ribonucleoprotein Sm-E, putative & 2,141 \\
\hline Тc00.1047053507681.60 & Hypothetical protein, conserved & 2,137 \\
\hline Tc00.1047053508153.620 & Hypothetical protein, conserved & 2,137 \\
\hline Tc00.1047053509733.134 & Hypothetical protein, conserved & 2,136 \\
\hline Tc00.1047053504643.20 & Hypothetical protein, conserved & 2,133 \\
\hline Тc00.1047053440099.19 & Hypothetical protein, conserved & 2,132 \\
\hline Тc00.1047053507019.83 & 40S ribosomal protein $\mathrm{S} 30$, putative & 2,128 \\
\hline Tc00.1047053508831.100 & Hypothetical protein, conserved & 2,128 \\
\hline Тc00.1047053508257.190 & Hypothetical protein, conserved & 2,123 \\
\hline Tc00.1047053504741.124 & Hypothetical protein, conserved & 2,110 \\
\hline Tc00.1047053511215.14 & Hypothetical protein, conserved & 2,108 \\
\hline Tc00.1047053511837.40 & Hypothetical protein, conserved & 2,105 \\
\hline Tc00.1047053503909.60 & Hypothetical protein, conserved & 2,103 \\
\hline Тc00.1047053506295.90 & Coatomer zeta subunit, putative & 2,098 \\
\hline Tc00.1047053506943.110 & Hypothetical protein & 2,089 \\
\hline Tc00.1047053507009.80 & Hypothetical protein, conserved & 2,088 \\
\hline Тc00.1047053506619.49 & Ras-related protein Rab21, putative & 2,088 \\
\hline Тc00.1047053507993.36 & Hypothetical protein, conserved & 2,087 \\
\hline Tc00.1047053506835.150 & Zinc-binding protein (Yippee), putative & 2,084 \\
\hline Tc00.1047053506435.460 & Hypothetical protein & 2,078 \\
\hline Тc00.1047053510257.24 & Hypothetical protein, conserved & 2,078 \\
\hline Тc00.1047053507649.90 & Hypothetical protein, conserved & 2,076 \\
\hline Тc00.1047053508955.10 & Syntaxin, putative & 2,075 \\
\hline Тc00.1047053508479.170 & Hypothetical protein, conserved & 2,072 \\
\hline Тc00.1047053507641.180 & Endochitinase, putative & 2,072 \\
\hline Tc00.1047053508277.300 & Hypothetical protein, conserved & 2,065 \\
\hline $\mathrm{Tc} 00.1047053507275 .24$ & Hypothetical protein, conserved & 2,059 \\
\hline Tc00.1047053507669.200 & Hypothetical protein, conserved & 2,055 \\
\hline Тc00.1047053504051.49 & Hypothetical protein, conserved & 2,055 \\
\hline Tc00.1047053506727.4 & Hypothetical protein, conserved & 2,054 \\
\hline Tc00.1047053510289.44 & Hypothetical protein, conserved & 2,053 \\
\hline Tc00.1047053507609.20 & Hypothetical protein, conserved & 2,045 \\
\hline Tc00.1047053507031.64 & Hypothetical protein, conserved & 2,043 \\
\hline Тc00.1047053506247.74 & Hypothetical protein, conserved & 2,039 \\
\hline
\end{tabular}




\begin{tabular}{|c|c|c|}
\hline Gene & Description & FC \\
\hline Тc00.1047053507979.20 & Hypothetical protein, conserved & 2,038 \\
\hline Тc00.1047053509601.160 & Hypothetical protein, conserved & 2,037 \\
\hline Тc00.1047053506743.190 & Hypothetical protein, conserved & 2,036 \\
\hline Тc00.1047053507997.80 & Hypothetical protein, conserved & 2,035 \\
\hline Тc00.1047053508177.20 & Carbohydrate kinase, thermoresistant glucokinase, putative & 2,035 \\
\hline Тc00.1047053506575.54 & Hypothetical protein, conserved & 2,027 \\
\hline Тc00.1047053507521.70 & Cyclophilin, putative & 2,023 \\
\hline Тc00.1047053506725.60 & Hypothetical protein, conserved & 2,023 \\
\hline Тc00.1047053508951.50 & Calmodulin, putative & 2,021 \\
\hline Тc00.1047053503575.34 & Ribosomal protein L38, putative & 2,018 \\
\hline Тc00.1047053508409.250 & Hypothetical protein, conserved & 2,016 \\
\hline Tc00.1047053508013.90 & Hypothetical protein & 2,010 \\
\hline Тc00.1047053504171.50 & Hypothetical protein, conserved & 2,009 \\
\hline Тc00.1047053504105.60 & Hypothetical protein, conserved & 2,009 \\
\hline Тc00.1047053507771.114 & Hypothetical protein, conserved & 2,007 \\
\hline Тc00.1047053506925.420 & Hypothetical protein, conserved & 2,004 \\
\hline Tc00.1047053507949.29 & Hypothetical protein, conserved & 2,003 \\
\hline
\end{tabular}

223 enriched genes observed in the three independent assays using Trypanosom cruzi oligonucleotide microarray analyzed by competitive hybridization using the non bound fraction as the reference population in dye-swap assays. FC: fold change. 